\title{
NARRATIVE LIVES: LITERARY SELF-MAKING IN QUEBEC'S FRANCOPHONE JEWISH MIGRANT LITERATURE
}

\author{
Yvonne VÖLKL (University of Graz)
}

\section{Introduction}

Recently, Europe has seen a growing number of migrants originating from Africa and especially the Middle East. News about mass migration from Syria and pictures of migrants with nothing more than their clothing have come to dominate news channels and social media platforms around the globe. However, migration is not a new phenomenon; for centuries people have left their native countries for various - often life threateningreasons, including armed conflict, political persecution, poverty or economic hardship.

Whenever people leave everything behind and start anew, they experience "at first a sense of loss, dislocation, alienation and isolation, which will lead to processes of acculturation" (Bhugra 2004: 129). Each migration movement-either planned in the long term or unplanned, either permanent or provisional, as in the case of a temporary study exchange or employment abroad- "involves the loss of the familiar, including language (especially colloquial and dialect), attitudes, values, social structures and support networks" (Bhugra/Becker 2005: 19). This 'cultural bereavement' has been defined by psychiatrist Maurice Eisenbruch as

\begin{abstract}
the experience of the uprooted person-or group-resulting from loss of social structures, cultural values and self-identity: the person — or group - continues to live in the past, is visited by supernatural forces from the past while asleep or awake, suffers feelings of guilt over abandoning culture and homeland, feels pain if memories of the past begin to fade, but finds constant images of the past (including traumatic images) intruding into daily life, yearns to complete obligations to the dead, and feels stricken by anxieties, morbid thoughts, and anger that mar the ability to get on with daily life. (Eisenbruch, quoted from Bhugra/Becker 2005: 19-20)
\end{abstract}

As recognized by psychiatrists and mental health professionals, one way to deal with these cultural bereavements is mourning, which is considered "a healthy reaction 
and a natural consequence of migration" (Bhugra/Becker 2005: 19; cf. Bhugra/ Craig/Bhui 2010; Bhugra/Gupta 2011). At this stage, some migrants take up the act of writing, which helps them to give meaning to the experiences of the past and to find some sort of guidance in the complex world around them. Those who take up paper and pencil, start to express in writing their particular situation, their torn up memory, and their questioned identity. ${ }^{1}$ In the course of the self-narration, the often traumatic experiences are ordered and a certain sense is attributed to them. According to narrative psychologists, the construction of his/her autobiographical story enables the writer to re-establish his/her coherent identity because "[...] narrative practices provide fundamental devices that give form and meaning to our experience" (Brockmeier/ Carbaugh 2001: 10). Due to the performative power of narratives, story-telling is even a crucial component when we want to understand ourselves and others as well as our relation to them (cf. Brockmeier/Carbaugh 2001).

Literary scholars Birgit Neumann and Ansgar Nünning, who in their article on interdisciplinary perspectives on narrative and identity discuss the connection between narrative, identity, and literature, explain the use of narratives as a way of self-making in the following way:

Stories establish the identity of the storyteller by creating chains of events and providing (causal) explanations for changes. In this vein, self-narrative is the very site where we give meaning to our autobiographical experiences and construct our identities by 'interweaving past and present experiences with the threads of a life history' (Brockmeier 2001: 456) [...] Through narrativization, heterogeneous and potentially ever-fluctuating experiences are transformed into a more or less coherent form, suggesting closure of one's life and relative stability of one's (diachronic) identity. (Neumann/Nünning 2008: 6; cf. Nünning et al. 2010)

Self-narration as a way of reconstructing one's identity can repeatedly be found within the novels of francophone Jewish migrant authors, where the reader encounters estranged migrant characters floating between past and present who try to overcome their cultural bereavement by telling the story of their life. Accordingly, the present paper will argue that the narrative self-making supports each character in his/her effort to reconstruct a coherent self, which is so necessary in order to lead a stable life. However, to begin with the article will briefly describe the context in which migrant literature and especially Franco-Jewish migrant literature arose in Quebec. On the basis of a dozen novels written by francophone Jewish migrant authors, it will then identify that all stories of migration are initiated at a specific moment which prompted the characters to reflect upon their past, present, and future. Subsequently, the article will focus on the particular memories that emerge during the process of self-making and will analyze what kinds of narrative strategies are used by the narrators in order to stress the memory process. In a final step, the article will approach the question of genre, given that the novels of the Franco-Jewish migrant authors are to be situated inbetween fiction and autobiography, and it will discuss to what extent this choice may affect the reader of the novels.

\footnotetext{
${ }^{1}$ Literary critics and migrant authors alike acknowledge that many migrants begin to write out of identity issues. They claim that writing provides them with a sense of home, allows them to find their way back to themselves, and to obtain a new place within the host society. See for instance: Ireland/Proulx 2009: 40; Lequin 2000: 117; Moisan/Moisan-Hildebrand 2001: 258265; Rachédi 2011: 40-47; Rushdie 1992.
} 


\section{Stories of Migration}

In his dictionary on immigrant authors in Quebec, Dictionnaire des écrivains émigrés au Québec, 1800-1999 (2003), Daniel Chartier shows that the literary landscape of Quebec has been considerably shaped by writers from abroad. Chartier established a list of approximately 600 authors, who, in the past two centuries, immigrated to Quebec for various reasons: from literary immigration to political refuge, from intersected paths to a short vacation that turned into a permanent residence (cf. Chartier 2002: 306). Chartier demonstrates that migrant authors from all four corners of the world have enriched and are still contributing to Quebec's literary corpus. Representatives of Quebec's Migrant Literature also include a small group of authors of Jewish origin who settled in Montreal and adopted the French language as their language of literary expression. This group is relatively modest due to the fact that, for many years, the Jewish community of Montreal primarily spoke Yiddish because of their Ashkenazi origin, and being closer to Montreal's anglophone community, adopted English as their second language. Consequently, Jewish Montreal writers, such as Mordecai Richler, Leonard Cohen, and A.M. Klein, chose to write in English. This changed at the end of the 1950s with the arrival of francophone Sephardic Jews from North Africa and the Middle East (cf. Robinson 2010: 33-4). Contemporary Sephardic novelists include Naïm Kattan (born in Iraq), Pierre Lasry (Morocco), Victor Teboul (Egypt) and Marc-Alain Wolf (France). Authors such as Monique Bosco (Austria) and Régine Robin (France) are of Ashkenazi descent, but write in French due to their education in the French school system.

In many of their novels, ${ }^{2}$ the aforementioned authors portray first or second generation immigrants of Jewish origin with a path of life similar to their creators. Very often, the characters are forced to leave their homeland because of political unrest. For instance, in both Monique Bosco's La femme de Loth and Charles Lévy, m.d., as well as in Naïm Kattan's La célébration, the impending approach of World War II prompts the parents of the protagonists to emigrate to Montreal. Similarly, in Kattan's Le veilleur, the main character's family flees Bagdad for New York. In Kattan's Adieu, Babylone and La fiancée promise, the repercussions of World War II equally prevent the protagonists from returning to Bagdad, their place of birth. In 1956, the Suez Canal crisis causes the exodus of Egyptian Jews, including the family of Victor Teboul's protagonist Maurice Ben Haïm, in Que Dieu vous garde de l'homme silencieux quand il se met soudain à parler and La lente découverte de l'étrangeté. Finally, the Balkan Wars prompt the emigration of the female non-Jewish character, Natasha, in Sauver le monde by Marc-Alain Wolf. These examples demonstrate that the migratory movement is in many cases imposed on the protagonists who would not otherwise have considered leaving their homes. In addition, beginning a new life in an unfamiliar place is an arduous task and often accompanied by feelings of regret, anger, and mourning. For those who barely survived the political unrest in their countries, the migratory movement symbolizes a socio-cultural uprooting and very often entails a destabilized identity. Many feel hostage to the past, especially when they experienced war and still suffer from its aftermath. Nonetheless, the migratory movement can have a positive effect on those who migrate considering its potential for reinvention and rebirth. Yet, before the protagonists can possibly revive and lead a self-determined life - free of the ghosts of their past - they are sooner or later obliged to face this difficult past.

\footnotetext{
${ }^{2}$ For the following study, twelve novels published between 1970 and 2009 by the aforementioned authors of Jewish origin have been used.
} 
In all francophone Jewish novels, memories appear at a specific moment in the lives of the protagonists. They generally emerge at so-called turning points, which are "those points of decisive moments at which a very significant change occurs, e.g. a change of direction or motion. Cases in point would be, for example, the 'turning point of her/his career' or the turning points in a war" (Nünning/Sicks 2012: 3). In the novels examined, these turning points recur as unexpected incidents which unsettle the lives of the protagonists, destabilize their mental health, and may even lead to an identity crisis. Such unexpected incidents tend to occur repeatedly when the protagonists reach middle age. One reason that this particular age group is more susceptible to these tendencies is that this stage is frequently characterized by biological, psychological, and social changes. Moreover, with age, people become increasingly aware of the passing of time; fatigue, illness and mortality are more likely to loom over them and strike without any warning (cf. Bellefleur-Raymond 2003: 14, 23).

In the novels, the turning points can be grouped into three categories: the changing of personal circumstances, the loss of a loved one, and the sudden perception that the end is approaching. Immigration and the ensuing sense of displacement provoke the retrospective moments experienced by the characters in Adieu, Babylone and La fiancée promise (Kattan), La Québécoite (Robin), as well as in Que Dieu vous garde... (Teboul). Eliahou becoming a grandfather in Le veilleur (Kattan) and Pierre's unforeseen religious aspiration in La célébration (Kattan), create a need for the protagonists to reflect upon the past. In La lente découverte de l'étrangeté (Teboul) and Kippour (Wolf), the impulse to look back is instigated by the death of the mother. In Don Juan et les moulins à vent (Lasry), this need is perpetuated by the death of a loved one, and in La femme de Loth (Bosco) by the swift end of a long love affair. Finally, the protagonists in Charles Lévy, m.d. (Bosco) and Sauver le monde (Wolf), are transported into the past while facing their own unexpected mortality.

The sudden exposure to changing personal circumstances and the experiences of loss and death challenge the identity of the characters and force them to reinterpret their lives. Thus, the turning point is the moment which prompts the characters to start reflecting upon their past and present, but also their future, leading them, on the one hand, to discover their true selves in this very moment of reinterpretation and, on the other hand, to understand the meaning of the past as well as to find a direction for the future (cf. Bellefleur-Raymond 2003: 37). In other words, the purpose of their narrative self-making, spanning over either the entirety or only parts of their lives, is to (re-)gain their biographical continuity, that is, to construct and reconstruct the meaning of life. To achieve this task, each one of them has to resolve the question: "How did I become the person I am today?" The answer to this question can only be found through the 'autobiographical process' (cf. Bruner 1993), i.e. the narrative reconstruction of one's own personal story. Within this process, a partial or entire biography is recreated through narrative, primarily by way of the protagonist's memory and remembrance. By remembering, the character attempts to (re-)organize the events of his/her past in order to place them within a broader context and find meaning in his/her personal life. However, memories of the past should not be mistaken for real experiences. Biographies are subjectively constructed and fictionalized by the autobiographer who modifies, supplements, or falsifies its fragments. In addition, during the process of memory retrieval, the narrative representation of memories is linked to the current situation of the remembering person because as Jerome Bruner notes: "[A] utobiography is not only [italics in the original] about the past, but is busily about the present as well" (Bruner 2001: 29). 


\section{Memory at Work}

The memories retrieved by the characters in Franco-Jewish novels derive from four principal thematic areas. First, many memories refer to the protagonists' childhood and adolescence. This is not surprising considering that the early years are the most formative in a person's life during which $\mathrm{s} / \mathrm{he}$ is exposed to many physical and psychological changes. In modern developmental psychology, the stages of life are generally described and separated according to the biological and social development of a person. Thus, childhood begins at birth, the transition from childhood to adolescence is characterized by sexual maturity, while the end of adolescence is determined by the acquisition of social roles, such as the beginning of a professional life, reaching legal age, getting married, or starting a family (cf. Grob/Jaschinski 2003: 17; Kimmel/Weiner 1995: 3; Oerter/Dreher 2002: 259). The sociologist Karl Mannheim (1893-1947) has shown that an individual's memory is most receptive during adolescence. The events that occur during this time influence the development of an individual's personality and all his/her subsequent life (cf. Assmann 2006: 26). The protagonists in La femme de Loth (Bosco), Adieu, Babylone (Kattan), La lente découverte de l'étrangeté (Teboul), as well as Le veilleur (Kattan) and Kippour (Wolf), primarily look back upon the memories from their childhood and youth.

Second, following a description of their early years, the characters repeatedly evoke memories of their migratory movement as well as their first experiences in the New World. For many protagonists, the city $^{3}$ is an attractive place to permanently establish themselves as it already offers the infrastructure that will allow them to find work and build a future for themselves and their families (cf. Mata Barreiro 1999: 256). Arriving in Montreal is central for the main characters in La fiancée promise (Kattan), La Québécoite (Robin), and Que Dieu vous garde... (Teboul). ${ }^{4}$ The parents of Eliahou in Le veilleur (Kattan) and those of Hélène in La femme de Loth (Bosco) try their luck in New York, but after some time the latter move on to Montreal, too. The Ben Haïm family in La lente découverte de l'étrangeté (Teboul) as well as the protagonist in La fiancée promise (Kattan) are exiled from Paris, and also choose Montreal as their new home. In Charles Lévy, m.d. (Bosco), La célébration (Kattan), Don Juan et les moulins à vent (Lasry), Kippour and Sauver le monde (Wolf), the city of Montreal does not play a central role, but still serves as a background for the stories.

Third, the memories of the protagonists revolve around the religion of their ancestors. Many of them have distanced themselves from their Jewish heritage during emigration and address the question of origin only after having been exposed to a significant life-changing event. Others go as far as re-reading core religious texts and embracing Jewish traditions and rituals. For example, Eliahou, the main character in Le veilleur (Kattan), reflects upon his trajectory from being a young teenager, doubting the existence of God, to the rabbinic life he leads at the time of narration. At the beginning of La célébration (Kattan) and Kippour (Wolf), the two male protagonists are not religious; soon, however, they engage in their neglected Jewishness in order to relate to

\footnotetext{
${ }^{3}$ Studies on Canadian immigration have revealed that Jewish immigrants principally settled in urban spaces, while a great number of Ukrainians, Scandinavians, Dutchmen, and Germans settled in rural areas of Canada (cf. Troper 2001).

${ }^{4}$ For a detailed description of urban Jewish immigration in these three novels, see Yvonne Völkl (2013): "L’arrivée en ville. La découverte de Montréal dans la littérature migrante juive au Québec."
} 
the legacy of their ancestors. This step towards their Jewish roots in later life helps them to both identify their own developmental path and to conceive of future projects.

Finally, novels such as Charles Lévy, m.d. (Bosco), Don Juan et les moulins à vent (Lasry) and Sauver le monde (Wolf), depict protagonists who are confronted with the fragility of human life. The way they respond to biological, psychological and social changes over the course of the Third Age (cf. Laslett 1991) is different in each case. Nevertheless, three common points can be identified. All of the male characters throw an interpretive glance at their past. Each one measures the dreams he desires and can still realize. Finally, each protagonist imagines how he will live on in the memories of the people who surround him. As a result, the three novels illustrate how the protagonists cope with the loss of mental and physical abilities and how they face mortality. Looking forward as well as back greatly helps the aging protagonists in building a coherent biography and in moving towards death without regrets.

\section{Narrative Representation of the Memory Processes}

Based on the assumption that no text is able to reproduce the authentic experience of 'remembering,' two German researchers, Michael Basseler and Dorothee Birke, have coined the term mimesis of memory (cf. Basseler/Birke 2005). By employing this term, they understand that any literary work generates "the illusion of an imitation of the process of remembering [...], rather than merely featuring a narrator or character who comments [italics in the original] on memory" (Birke 2006: 209-10). The starting point of their reflection is both Gérard Genette's structuralistic concept of mimesis and, Paul Ricœur's hermeneutic model. According to Genette, "no narrative can 'show' or 'imitate' the story it tells. All it can do, is tell it in a manner which is detailed, precise, 'alive,' and in that way give more or less the illusion of mimesis [italics in the original]" (Genette 1980: 164). Ricœur has developed the model of the threefold mimesis (cf. Ricœur 1984: 52-87), by which he explains the connection between the world of the reader and the world of the text. This model specifies that each story is rooted in an extra-textual world. This pre-narrative context serves as the basis for the prefiguration of the story $\left(\right.$ mimesis $\left._{1}\right)$. Mimesis M $_{2}$ concerns the narrative configuration of a story, which is realized by the act of emplotment - when extra-textual world and fictional events are connected within a story - and by the readers' construction of the narrative text-world, hence, the "mediating function" (Ricœur 1984: 65) of mimesis 2 . Finally, each time the story is read, the world of the text is reconfigured by the reader who establishes a connection between the world of the text and his own world (mimesis ( $_{3}$ ).

With regards to the mimesis of memory, the act of remembering itself cannot be imitated genuinely within a text; only an illusion of the mimesis of memory can be staged. By means of specific narrative techniques, which depict different processes of memory, varying degrees of the mimesis illusion of the memory processes can be gathered within a story. As noted by Basseler and Birke, there are two prerequisites for the occurrence of the mimesis of memory: a text can only stage the act of remembering if it 1) displays a subjective center of perception from the beginning onwards, and 2) has at least two levels of narration (cf. Basseler/Birke 2005: 124-5), for example, a 'first narrative' and an embedded subordinate narrative. ${ }^{5}$

In francophone Jewish novels, most of the stories are told from the perspective of a first-person narrator, i.e. a narrating $I$, who talks about his/her present and past.

\footnotetext{
${ }^{5}$ The term 'first narrative' was coined by Gérard Genette, who used this term to designate any "temporal level of narrative with respect to which anachrony is defined" (Genette 1980: 48).
} 
Whenever s/he mentions past episodes, the narrating $I$ turns into a remembering $I$. Memories of the past take place either involuntarily or voluntarily. Similarly to Proust's famous episode of the madeleine, in which the taste of a French cake enables the narrator to 'experience' the past within the present moment, the memories 'visit' many protagonists unexpectedly in the middle of the night or following the exposure to a certain taste, smell, sight or sound. In Kippour (Wolf), for instance, the sound emanating from a shofar used by one of the main character's sons triggers a memory in an aged guest during the celebrations at the end of Yom Kippur. Alternatively, the images of the past are voluntary evoked when, for example, Maurice Ben Haïm, the middle-aged male character in La lente découverte de l'étrangeté (Teboul) questions his father about the reasons why his family did not hold Egyptian citizenship at the time of the Suez canal crisis. The father responds:

Les Égyptiens n'accordaient pas aussi facilement leur citoyenneté, m'expliqua-t-il patiemment. Nous, les juifs, avions beau connaître leur langue à la perfection et avoir eu des ministres à la cours, rien à faire. Il fallait prouver, surtout durant la guerre de Suez, que nous étions établis là depuis des générations. (Teboul 2002: 65)

[The Egyptians did not easily grant citizenships, he explained to me patiently. We, the Jews, could, indeed, speak their language perfectly and have had ministers at the court, yet it changed nothing. We had to prove, especially during the Suez Crisis, that we had been established here for generations. (My translation)].

As can be seen in the excerpt above, the memories-either voluntary or involuntary - are usually narrated in the French past tenses (passé simple, imparfait, passé composé), which can be ascribed to their bygone character. If the images of past episodes appear in chronological order, from birth to adolescence to adulthood, the character has usually constituted his/her biographical continuity. If, however, the narrative coherence breaks down, the character might not have completely assimilated the events of the past until now - the moment of narration. At the level of discourse, this lack of biographical continuity reveals itself either when the past is not presented chronologically or when there are rapid changes between the narrator's present point of view and his/her past consciousness.

Depending on whether memories are narrated from the perspective of the older, more experienced narrator, or his/her younger self, one can distinguish between two forms of the narrated self: an experiencing $I$ and a remembered I (cf. Basseler/Birke 2005: 137-8). In those cases in which the narrator (remembering I) adopts the limited vision of his/her younger self, the reader is confronted with the voice of the experiencing $I$. This voice comes to life when the narrator suddenly delves deeply into the past. Consequently, the reader gets the impression that the narrator is once again 'experiencing' the events which s/he is actually just about to remember. On a discursive level, the following three characteristics suggest the presence of an experiencing $I$ : the narrator seems absent; memories are suddenly observed in the present tense (présent historique); dialogue is accompanied less frequently by introductory verbs. The narration of past events in the historical present and their presentation in dramatic mode render the past events more lively and topical, and simultaneously create the impression that the character remains enveloped in his/her past story.

The experiencing $I$ is demonstrated in La fiancée promise (Kattan), when at the beginning of the novel, the male protagonist, Méir, recalls his very first arrival at Montreal's train station and the first glimpses of his new home. In the excerpt below, the memories of the first-person narrator are presented in the past tense at first, then 
suddenly, the narration changes into the present tense in order to express the emotional intensity and the high significance of the protagonist's arrival in Canada:

\begin{abstract}
Je regardai la gare neuve et propre. Je me disais : ,C'est cela l'Amérique.' J'y étais. La neige tombe et sur le sol une couche blanche se dresse comme un écran qui couvrirait un pays interdit. Où aller? Je téléphone au YMCA. Oui, il y a une chambre, mais il faut attendre jusqu'à midi pour en prendre possession. Il est neuf heures. Trois heures de liberté. Le pays est à moi et je suis maître de mes actes et j'ai peur de la neige. (Kattan 1983: 8)

[I looked at the new and clean train station. I told myself: 'This is America.' There I was. The snow falls and a white layer forms on the ground resembling a screen that could cover the entirety of a forbidden country. Where to go? I phone the YMCA. Yes, there is a free room, but I have to wait until noon to get it. It is nine o'clock. Three hours of freedom. The country is mine and I am the master of my actions and I am afraid of the snow. (My translation)].
\end{abstract}

Another way for the narrator to tell the story of his/her own past is to present it through the perspective of the remembered $I$. This way of narrating differs from that described above insofar as the focus is now not exclusively on the experiencing $I$ of the past, but on both the present narrator and his/her younger self. In other words, here the narrator is not entrenched within his/her character when s/he tells past events, but instead constantly reminds the reader that $\mathrm{s} / \mathrm{he}$ is providing the retrospective. This remembered $I$ emerges when the narrator comments on his/her childhood or the past in general. Using evaluative formulations, such as 'Today, I know that...,' the narrator demonstrates the expanded knowledge s/he has today - at the moment of narration. The reader is also confronted with numerous changes between the different levels of narration, i.e. frequent moves between the narrative levels of the past and the present. In addition, the remembered I appears each time the narrator makes use of the rhetoric of memory (cf. Löschnigg 1999), occurring in situations in which the narrator explicitly articulates that $\mathrm{s} / \mathrm{he}$ remembers, that $\mathrm{s} /$ he has forgotten, or that $\mathrm{s} /$ he does not remember clearly. One of many examples of a remembered I can be found in Don Juan et les moulins à vent (Lasry) in which the protagonist, Henry Wise, recalls a meeting with Naomi in his office. This memory is introduced by means of the following rhetoric of memory: "Notre deuxième rencontre me revient à l'esprit. [Our second meeting comes to my mind (my translation)]" (Lasry 2008: 69). In the subsequent sentence, Henry's remembered $I$ is revealed. In the following paragraph, the perspective changes to Henry's experiencing I, where the use of the present tense suggests that Henry literally sees Naomi in his mind's eye:

Notre deuxième rencontre me revient à l'esprit. [Naomi] travaillait au journal au classement du courrier. [...]. Il y a un an déjà.

Naomi est inconfortablement accroupie sur le plancher, près de la photocopieuse entre deux grosses boîtes de cartons pleines de documents. [...].

Naomi a l'air de ne pas savoir quoi faire. (Lasry 2008: 69-70)

[Our second meeting comes to my mind. [Naomi] worked at the newspaper where she sorted the mail. [...]. One year has passed already.

Naomi is uncomfortably crouched on the floor beside the photocopy machine between two large cardboard boxes full of documents. [...].

Naomi looks as if she does not know what to do. (My translation)].

In the two examples mentioned above, the narrative levels of the present (where the remembering $I$ is located) and of the past (where the experiencing $I$ and the 
remembered I are located) can be clearly distinguished. They also appear well-balanced as they take up a similar amount of narrative space. As a result, the mimesis of memory within these two examples is very high. However, following the aforementioned scene of Méir's arrival in Montreal, this equilibrium between past and present dissipates in favor of the retrospect, in which the narrator does not make any further comments on his past experiences. Seen in its entirety, the novel La fiancée promise does not indicate many memory processes. The reader is even inclined to completely forget that the text is about the memories of a narrating $I$. In spite of the first impression, the illusion of the mimesis of memory is less intense or even completely elusive in this novel. Consequently, because the mimesis illusion of the memory processes varies throughout almost all the novels analyzed, the degree of the mimesis of memory can only be indicated as high, middle, or low for each novel.

\section{Fictional Translation of Lives}

Hitherto, the study concentrated on the intratextual voices within the novels by Quebec's Franco-Jewish migrant authors and revealed that their memories of the past envelop the narrators/protagonists at specific moments of their lives. It demonstrated that their narrative self-making revolves around similar thematic fields and illustrated that their memory work is accompanied by specific narrative strategies, which are employed to highlight the memory process. In the final part, the article will discuss why the migrant authors may have opted for a fictional translation of their life instead of composing an autobiography. Ultimately, it will touch upon the question of how blurring the lines between autobiography and fiction influences the reception of the novels.

The writings of the francophone Jewish authors can neither be interpreted as autobiographies due to their lack of what Philippe Lejeune called the 'autobiographical pact,' nor can they be exclusively understood as fictional life accounts because of the choice of migrant characters as the main protagonists, who, predominantly as firstperson narrators, recount their lives against a factual historical background. Rather, they are to be situated in-between genres, much like Canadian-Jewish authors have been characterized by Michael Greenstein as experiencing 'third solitude' in-between the anglo- and francophone Canadian 'two solitudes,' in a space in-between the New and the Old World, from where they "attempt to mediate [italics in the original] between tradition and modernism, home and exile, Jewish-Canadian particularism and universal significance" (Greenstein 1989: 3). ${ }^{6}$ In this state of in-betweenness, the creative process becomes central to the negotiation of past events, to the interpretation of the environment, to the examination of self-development as well as to the (re-)establishment of a coherent identity.

In the afterword of the novel La Québécoite (engl. The Wanderer), Régine Robin, for example, considers literature to be a "[...] specific place for the play of imagination, experimentation, and questioning of one's own identity/ies" (Robin 1997: 179). She even assigns a therapeutic function to writing and admits that creating this book was indeed like therapy for her (cf. Robin 1997: 173). The process of writing, of expressing on paper her positive and negative feelings towards her migrant position in Montreal

\footnotetext{
${ }^{6}$ Of course, this specific state of in-betweenness is not only characteristic for Jewish migrant authors, but for migrant authors in general, whose texts repeatedly approach the themes of exile, culture shock, identity loss, and the reworking of individual and collective memory, and result in innovative, often hybrid forms of writing (cf. Dupuis 2008: 506; Ireland/Proulx 2009).
} 
helped her to 'become friends' with this new and allegedly hostile place. Robin claims that if she had not written the novel, she would most likely have gone back to Francejust like her character. Further, she explains:

I wrote it because it allowed me to explore a problem that I was unable to express in other ways. One leitmotif in the book is that one does not become Québécois. After writing the book I understood that becoming Québécois was no longer of any importance to me. The Wanderer deals with the problem of finding a place for oneself here and making one's voice heard when one comes from elsewhere, and once the book was finished, I felt that this was possible through writing, through social involvement, through the practice of one's craft, through friendship and other relationships [...]. (Robin 1997: 174)

After mentioning the therapeutic function of writing, Robin alludes to the testimonial function of writing in the quotation above. From a personal view point, she highlights the preconceptions of the host society she had to face while trying to blend in. In addition, Robin addresses the desire to be accepted (recognition function), a wish we might all have already experienced, but which is even more difficult to attain for people originating from a different linguistic, cultural, ethnic or religious background. As we learn from La Québécoite, even having the same mother tongue does not spare us from cultural misunderstandings: "Je ne comprenais pas le pourquoi des ventes sales, sinon qu'elles n'étaient pas le contraire des ventes propres“" (Robin 1993: 54) ["I didn't understand what 'ventes sales' were, but they were not 'dirty sales"' (Robin 1997: 39)]. Due to the lack of a visual dividing line between the French word 'ventes' and its English equivalent 'sales,' the narrator-protagonist is not able to decode this simple message announcing the clearance sale in both languages.

The therapeutic, testimonial, and recognition functions of writing mentioned by Régine Robin, have also been revealed by UQAM School of Social Work professor Lilyane Rachédi (2011), who, in her article on autobiographical writing in migrant contexts, specifies a fourth function of literary self-making which may contribute to the identity construction of migrants and their integration into the host society: the ludic function. This function also appears in Robin's novel, which is a playful collage of memorial fragments, languages, impressions (e.g. lists of metro stations), types of texts (e.g. newspaper clippings, political manifestos, memoires), different narrative levels, etc.

Caught between cultures, languages, modes of living, religions, societies, etc., the migrant authors cannot describe their path of life with conventional modes of expression. It seems as if their exceptional path needs new, exceptional ways of expression. In this respect, it seems logical that the authors chose not to directly refer to themselves, but to disassociate themselves from their own life through fictionalization. And even if they had tried to compose their autobiography, would it not just have been a narrative reconstruction and subjective interpretation of their own life and thus, again not be a true, but a rather fictional image of the self? In fact, as we have learned from psychologists and psychiatrists, the autobiographical self is always reconstructed from the present point of view of the one who remembers. Accordingly, it is a product of memory and, as most of us would agree, nothing is more fallible than our memory. Depending on our present situation, our narrated self is most likely to vary each time we narrate our life, so that today we may highlight specific aspects of our existence that in a year will have become totally obsolete.

Considering the reception of these-what we might more accurately callautofictional novels, it is important to recognize that they represent perspicacious 
observations of the world and the relation between historical events and individual lives. By virtue of the broader historical context addressed in the Franco-Jewish novels, they provide the reader with valuable information on the historical reasons for Jewish emigration and the specific trajectories of Jewish immigrants to North America, and give an informative overview of the development and integration of the francophone Jewish community in Montreal. Furthermore, the texts reveal particular social structures present within Montreal - particularly between the 1960s and 1980s - and show how the francophone Jews were received by societies already well established there (French-Catholics, Anglo-Protestants, and Anglo-Jewish). For a reader unfamiliar with Judaism, some texts also allow the discovery of the traditions and religious practices present within Montreal's Jewish communities.

Regarding the representation of specific individual self-making processes, it can be argued that the novels also have a guiding function. Reverting to Ricœur's argumentation of the threefold mimesis, the reader establishes in the act of reading (mimesis $)_{3}$ a connection between the textual world and his/her own world, which may transform his/her future actions. In this respect, the novels written by the FrancoJewish migrant authors offer a range of behavioral patterns of how to interpret and approach the environment, how to deal with losses or how to confront the ghosts of the past. It no longer matters whether the characters and what they experience is fictional or factual, because they are described as humans in a world similar to our own. Therefore, the most important aim is not to find an answer to whether the stories told exactly reflect reality, but rather to ask whether the reader can connect to the textual world and its inhabitants.

\section{WORKS CITED:}

Assmann, Aleida. 2006. Der lange Schatten der Vergangenheit: Erinnerungskultur und Geschichtspolitik. München: C.H. Beck;

Basseler, Michael, and Dorothee Birke. 2005. "Mimesis des Erinnerns," in: Astrid Erll and Ansgar Nünning (eds.). Gedächtniskonzepte der Literaturwissenschaft. Theoretische Grundlegung und Anwendungsperspektiven. Berlin: de Gruyter, 123-147;

Bellefleur-Raymond, Denise. 2003. Trois défis du mitan de la vie. Montréal: Fides;

Bhugra, Dinesh and Susham Gupta (eds.). 2011. Migration and Mental Health. Cambridge: Cambridge University Press;

Bhugra, Dinesh, and Matthew A. Becker. 2005. "Migration, Cultural Bereavement and Cultural Identity." World Psychiatry 4, no. 1, 18-24;

Bhugra, Dinesh, Tom Craig, and Kamaldeep Bhui (eds.). 2010. Mental Health of Refugees and Asylum Seekers. Oxford: Oxford University Press;

Bhugra, Dinesh. 2004. "Migration, Distress and Cultural Identity." British Medical Bulletin 69, no. 1, 129-141;

Birke, Dorothee. 2006. "Mimesis of Memory: Representation of Time in Guy Burt's Novel The Dandelion Clock," in: Ansgar Nünning, Marion Gymnich and Roy Sommer (eds.). Literature and Memory. Tübingen: Francke, 209-222;

Bosco, Monique. 1977. Charles Lévy, m.d. Montréal: Quinze;

Bosco, Monique. 2003. La femme de Loth. Montréal: Bibliothèque québécoise. (Original work published 1970);

Brockmeier, Jens and Donal A. Carbaugh (eds.). 2001. Narrative and Identity: Studies in Autobiography, Self and Culture. Amsterdam [et al.]: Benjamins;

Bruner, Jerome. 1993. "The Autobiographical Process," in: Robert Folkenflik (ed.). The Culture of Autobiography. Stanford, CA: Stanford University Press, 38-56; 
Bruner, Jerome. 2001. "Self-Making and World-Making," in: Jens Brockmeier and Donal A. Carbaugh (eds.). Narrative and Identity: Studies in Autobiography, Self and Culture. Amsterdam [et al.]: Benjamins, 25-37;

Chartier, Daniel. 2002. "Les origines de l'écriture migrante. L'immigration littéraire au Québec au cours des deux derniers siècles." Voix et Images: littérature québécoise 80, 303-316;

Chartier, Daniel. 2003. Dictionnaire des écrivains émigrés au Québec. 1800-1999. Québec: Éditions Nota bene;

Dupuis, Gilles. 2008. "Transculturalism and écritures migrantes," in: Reingard M. Nischik (ed.). History of Literature in Canada: English-Canadian and French-Canadian. Rochester, NY [et al.]: Camden House, 497-508;

Genette, Gérard. 1980. Narrative Discourse: An Essay in Method. Ithaca, NY [et al.]: Cornell University Press;

Greenstein, Michael. 1989. Third Solitudes: Tradition and Discontinuity in Jewish-Canadian Literature. Kingston, ONT; Montreal: McGill-Queen's University Press;

Grob, Alexander, and Uta Jaschinski. 2003. Erwachsen werden. Entwicklungspsychologie des Jugendalters. Weinheim [et al.]: Beltz;

Ireland, Susan, and Patrice J. Proulx. 2009. "Negotiating New Identities in Quebec's écriture migrante." Contemporary French \& Francophone Studies 13, no. 1, 35-43;

Kattan, Naïm. 1997. La célébration. Montréal: L'Hexagone;

Kattan, Naïm. 2003. Adieu, Babylone: mémoires d'un Juif d'Irak. Paris: Albin Michel. (Original work published 1975);

Kattan, Naïm. 2009. Le veilleur. Montréal: Hurtubise HMH;

Kattan, Naïm.1983. La fiancée promise. Montréal: Hurtubise HMH;

Kimmel, Douglas C., and Irving B. Weiner. 1995. Adolescence: A Developmental Transition. New York [et al.]: John Wiley \& Sons, Inc.;

Laslett, Peter. 1991. A Fresh Map of Life. The Emergence of the Third Age. Cambridge, MA: Harvard University Press;

Lasry, Pierre. 2008. Don Juan et les moulins à vent. Montréal: Éditions Du Marais;

Lequin, Lucie. 2000. "Écrivaines migrantes et éthiques," in: Anne de Vaucher Gravili (ed.). D’autres rêves. Les écritures migrantes au Québec. Venezia: Supernova. 113-41;

Löschnigg, Martin. 1999. “"The prismatic hues of memory'. Autobiographische Modellierung und die Rhetorik der Erinnerung in Dickens' David Copperfield." Poetica 31, 1-2, 175-200;

Mata Barreiro, Carmen. 1999. "Regard immigrant sur la ville et voix immigrantes dans la ville. Témoignages littéraires," in: Lucie K. Morisset, Luc Noppen and Denis Saint-Jacques (eds.). Ville imaginaire, ville identitaire: échos de Québec. Québec: Éditions Nota bene, 253-267;

Moisan, Clément, and Renate Hildebrand. 2001. Ces étrangers du dedans: une histoire de l'écriture migrante au Québec (1937-1997). Québec: Éditions Nota bene;

Neumann, Birgit, and Ansgar Nünning. 2008. "Ways of Self-Making in (Fictional) Narrative: Interdisciplinary Perspectives on Narrative and Indentity," in: Birgit Neumann, Ansgar Nünning and Bo Pettersson (eds.). Narrative and Identity: Theoretical Approaches and Critical Analyses. Trier: WVT, 3-22;

Nünning, Ansgar, and Kai M. Sicks. 2012. "Turning Points as Metaphors and Mininarrations: Analysing Concepts of Change in Literature and Other Media," in: Ansgar Nünning and Kai M. Sicks (eds.). Turning Points: Concepts and Narratives of Change in Literature and Other Media. Berlin [et al.]: de Gruyter, 1-28;

Nünning, Ansgar, Vera Nünning, and Birgit Neumann (eds). 2010. Cultural Ways of Worldmaking: Media and Narratives. Berlin [et al.]: de Gruyter;

Oerter, Rolf, and Eva Dreher. 2002. "Kapitel 7, Jugendalter," in: Rolf Oerter and Leo Montada (eds.). Entwicklungspsychologie. $5^{\text {th }}$ ed. Weinheim [et al.]: Beltz, 258-318;

Rachédi, Lilyane. 2011. "Écrire son histoire en contexte d'immigration." Équilibre 6, no. 1, 4047;

Ricœur, Paul. 1984. Time and Narrative: Vol. 1. $5^{\text {th }}$ ed. Chicago, Ill. [et al.]: University of Chicago Press;

Robin, Régine. 1993. La Québécoite. $2^{\text {nd }}$ ed. Montréal: XYZ. (Original work published 1983); 
Robin, Régine. 1997. The Wanderer [La Québécoite]. Trans. by Phyllis Aronoff. Montreal: Alter Ego;

Robinson, Ira. 2010. "Le judaïsme à Montréal," in: Pierre Anctil and Ira Robinson (eds.). Les communautés juives de Montréal. Histoire et enjeux contemporains. Sillery, QC: Septentrion, 23-37;

Rushdie, Salman. 1992. Imaginary Homelands: Essays and Criticism, 1981-1991. $2^{\text {nd }}$ ed. London: Granta Books;

Teboul, Victor. 1999. Que Dieu vous garde de l'homme silencieux quand il se met soudain à parler. Montréal: Les Intouchables;

Teboul, Victor. 2002. La lente découverte de l'étrangeté. Montréal: Les Intouchables;

Troper, Harold. 2001. "New Horizons in a New Land: Jewish Immigration to Canada," in: Ruth Klein and Frank Dimant (eds.). From Immigration to Integration: The Canadian Jewish Experience: A Millennium Edition. Toronto: The Institute for International Affairs \& B'nai Brit Canada. Accessed September 2, 2010.http://www.bnaibrith.ca/institute/millennium/ millennium01.html;

Völkl, Yvonne. 2013. "L’arrivée en ville. La découverte de Montréal dans la littérature migrante juive au Québec," in: Anne Brüske and Herle-Christin Jessen (eds.). Dialogues transculturels dans les Amériques: Nouvelles littératures romanes à Montréal et à New York. Tübingen: Narr, 185-198;

Wolf, Marc-Alain. 2006. Kippour. Montréal: Triptyque;

Wolf, Marc-Alain. 2009. Sauver le monde. Montréal: Triptyque.

\section{NARRATIVE LIVES: LITERARY SELF-MAKING IN QUEBEC'S FRANCOPHONE JEWISH MIGRANT LITERATURE}

To this day, the number of Jewish migrant authors of French-language literature has remained relatively small compared to the large number of authors considered as part of Quebec's écritures migrantes. Monique Bosco, Naïm Kattan, Pierre Lasry, Victor Teboul, Régine Robin, and MarcAlain Wolf, are just some, amongst a host of other migrant authors of Jewish origin. Migrant characters who have started a new life in Montreal are often the protagonists of these authors' novels in which a similarity to the author's biographies cannot be overlooked. The new lives that the migrant characters lead are more often than not marked and sometimes even haunted by their past. By remembering what happened to them and by telling the story of their life, the narrators/protagonists try to reconstruct a coherent self-identity. Therefore, the article will focus on the particular memories emerging in the process of self-making and will examine the narrative strategies used to highlight the memory process. In a final step, the article will ask to what end the authors may have set their narratives in-between the fictional and the factual genre and what this means for the reception process.

KEYWORDS: Canadian Jewish literature; francophone literature; écriture migrante; autobiography; identity, memory; Monique Bosco; Naïm Kattan; Pierre Lasry; Victor Teboul; Régine Robin; Marc-Alain Wolf.

\section{ŻYCIE W OPOWIEŚCI. STAWANIE SIE SOBA POPRZEZ LITERATURE WE FRAN- KOFOŃSKIEJ TWÓRCZOŚCI ŻYDOWSKICH MIGRANTÓW W QUEBECU}

Liczba pisarzy francuskojęzycznych żydowskiego pochodzenia pozostaje stosunkowo niewielka $\mathrm{w}$ zestawieniu z olbrzymim gronem innych autorów migracyjnych w Quebecu. Do autorów pochodzenia żydowskiego należą między innymi Monique Bosco, Naïm Kattan, Pierre Lasry, Victor Teboul, Régine Robin i Marc-Alain Wolf. Bohaterami ich powieści, często autobiograficznych, są imigranci, którzy rozpoczynają wszystko od nowa po osiedleniu się w Montrealu. Jednak to ich nowe życie bywa naznaczone, a nawet nawiedzane przez przeszłość. Wspominając wcześniejsze życie i opowiadając o nim, bohaterowie i narratorzy próbują zrekonstruować swoją spójną tożsamość. Celem niniejszego artykułu jest analiza roli, jaką w procesie stawania się sobą 
pełnią wspomnienia, oraz strategii narracyjnych, służących wyrażaniu pracy pamięci. Artykuł stawia również pytanie o funkcję usytuowania badanych utworów na granicy fikcji i autobiografii oraz wpływ takiego usytuowania na proces odbioru.

SŁOWA KLUCZOWE: frankofońska literatura kanadyjska; literatura kanadyjsko-żydowska; literatura migrantów; autobiografia; tożsamość; pamięć; Monique Bosco; Naïm Kattan; Pierre Lasry; Victor Teboul; Régine Robin; Marc-Alain Wolf. 